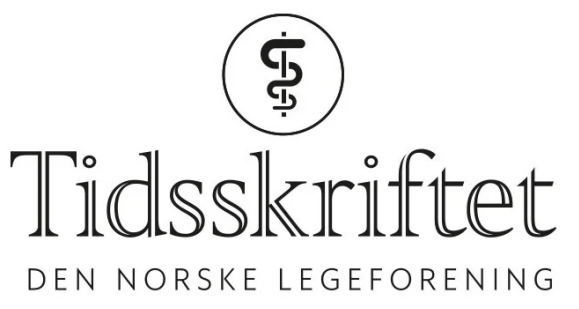

\title{
Ultralyd ved langvarige fødsler
}

NYHETER

SIGURD HØYE

Email: sigurd.hoye@legeforeningen.no

Tidsskriftet

Ultralyd er et godt diagnostisk verktøy til å vurdere fødsler med langsom fremgang. 


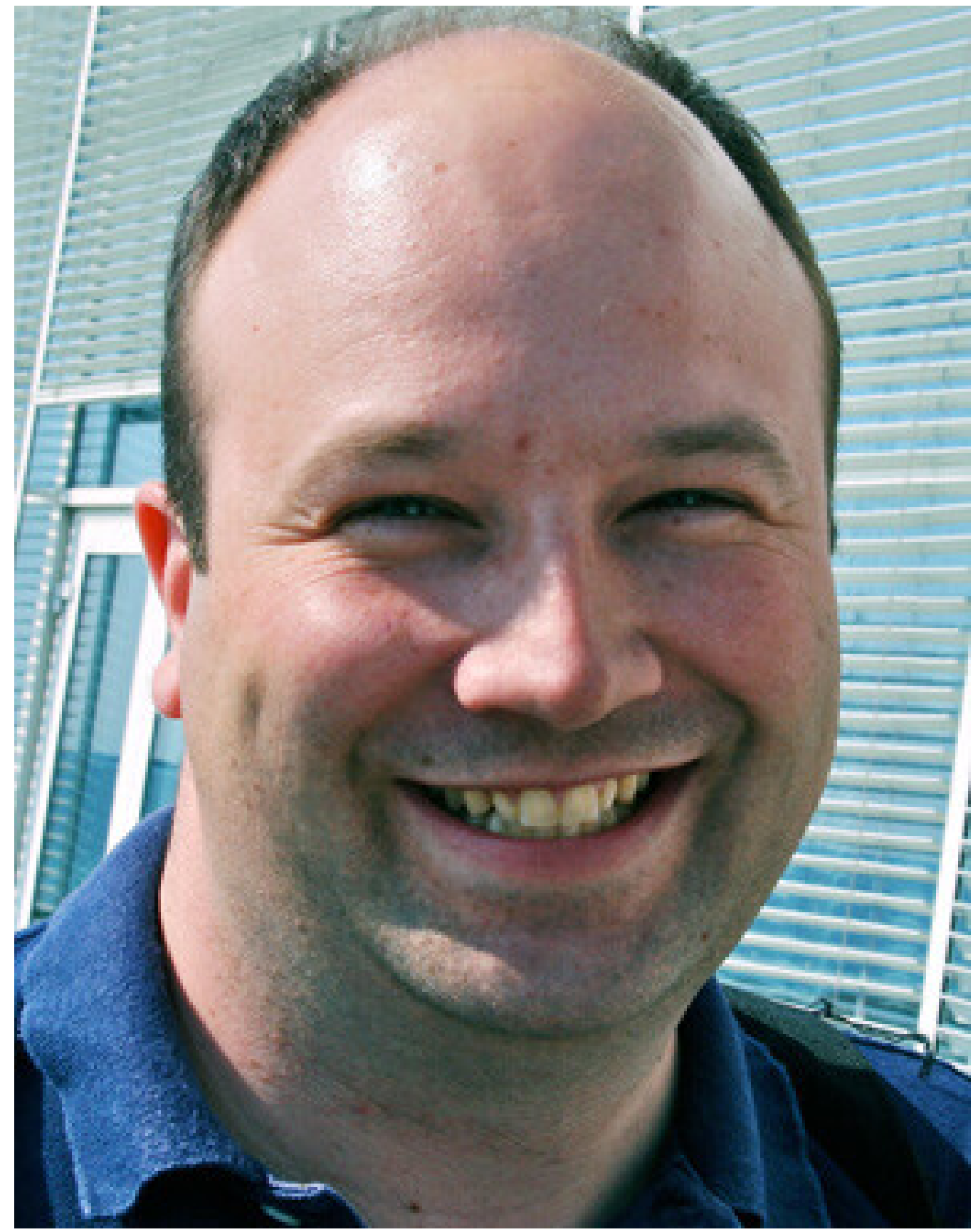

Erik Andreas Torkildsen. Foto privat

De fleste fødsler forløper uten alvorlige problemer, men langsom fremgang er vanlig hos førstegangsfødende. Åsaker rkan være dårlige rier, feilinnstilling, stort foster eller trangt bekken. Tradisjonelt vurderer fødselshjelpere fødselens fremgang med hendene, men dette er en subjektiv undersøkelse. Ultralydunders $\emptyset$ kelse blir mye brukt i løpet av svangerskapet, men lite under selve fødselen. Bør ultralydapparatet flyttes inn på fødestuene?

I sitt doktorgradsprosjekt har Erik Andreas Torkildsen undersøkt 110 førstegangsfødende med langsom fremgang i første stadium. Hovedeffektmål var vaginal fødsel versus keisersnitt. Fosterhodets nivå og posisjon i fødselskanalen ble undersøkt med ultralyd. Dette ble sammenliknet med tradisjonell klinisk undersøkelse. Det ble brukt to målemetoder for nivå: avstanden fra fosterhodet til perineum (avstandsmetoden) og vinkelen mellom fosterhodet og symfysen (vinkelmetoden). Dessuten ble det anvendt både to- og tredimensjonal ultralydteknikk.

Hvis fødselen stoppet opp når hodet lå høyt i fødselskanalen, var det stor risiko for keisersnitt, men dersom hodet hadde passert midtre del av kanalen, fødte $90 \%$ av kvinnene vaginalt. Fosterhodets posisjon i bekkenet hadde liten betydning for det videre fødselsforløpet, trolig fordi hodet vanligvis roterer spontant. 
- Avstandsmetoden og vinkelmetoden samsvarte godt, og resultatene fra to- og tredimensjonal teknikk var likeverdige. Todimensjonal teknikk bør derfor foretrekkes fordi det er en enklere undersøkelse og utstyret er rimeligere, sier Erik Andreas Torkildsen.

- Ultralyd er en mer objektiv teknikk enn manuell undersøkelse og kan gjøre det lettere for fødselshjelperen å stille mer nøyaktige diagnoser. Undersøkelsen med ultralyd er rask og enkel og gir informasjon direkte på fødestuen. Dette vil kunne gjøre det enklere å vurdere det rette tidspunktet for eventuelt keisersnitt og unngå unødvendige keisersnitt, sier Torkildsen.

\section{Disputas}

Erik Andreas Torkildsen disputerte for ph.d.-graden ved Norges teknisknaturvitenskapelige universitet 20. 9. 2013. Tittelen på avhandlingen er Ultrasound \& prediction of prolonged labor.

Publisert: 26. november 2013. Tidsskr Nor Legeforen. DOI:10.4045/tidsskr.13.1423

(C) Tidsskrift for Den norske legeforening 2023. Lastet ned fra tidsskriftet.no 26. april 2023. 